\title{
Socio-religious implications of the bond between democracy and theocracy in Nigeria
}

\begin{tabular}{|c|c|}
\hline \multicolumn{2}{|c|}{$\begin{array}{l}\text { Authors: } \\
\text { Benjamin Diara' } \\
\text { Favour Uroko } 0^{1,2}\end{array}$} \\
\hline \multicolumn{2}{|c|}{$\begin{array}{l}\text { Affiliations: } \\
\text { }{ }^{1} \text { Department of Religion and } \\
\text { Cultural Studies, University of } \\
\text { Nigeria, Nsukka, Nigeria }\end{array}$} \\
\hline \multicolumn{2}{|c|}{$\begin{array}{l}{ }^{2} \text { Department of New } \\
\text { Testament and Related } \\
\text { Literature, Faculty of } \\
\text { Theology and Religion, } \\
\text { University of Pretoria, } \\
\text { Pretoria, South Africa }\end{array}$} \\
\hline \multicolumn{2}{|c|}{$\begin{array}{l}\text { Research Project Registration: } \\
\text { Project Leader: E. van Eck (1) } \\
\text { Project Number: } 2400030\end{array}$} \\
\hline \multicolumn{2}{|c|}{$\begin{array}{l}\text { 'Hermeneutics and Exegesis’ } \\
\text { directed by Prof. Dr Ernest } \\
\text { van Eck, Department of } \\
\text { New Testament and } \\
\text { Related Literature, Faculty } \\
\text { of Theology and Religion, } \\
\text { University of Pretoria. }\end{array}$} \\
\hline \multicolumn{2}{|c|}{$\begin{array}{l}\text { Corresponding author: } \\
\text { Favour Uroko, } \\
\text { favour.uroko@unn.edu.ng }\end{array}$} \\
\hline $\begin{array}{l}\text { Dates: } \\
\text { Received: } 01 \wedge \\
\text { Accepted: } 05 \\
\text { Published: } 29\end{array}$ & $\begin{array}{l}\text { Jov. } 2018 \\
\text { Aug. } 2019 \\
\text { Jan. } 2020\end{array}$ \\
\hline \multicolumn{2}{|c|}{$\begin{array}{l}\text { How to cite this article: } \\
\text { Diara, B. \& Uroko, F., 2020, } \\
\text { 'Socio-religious implications of } \\
\text { the bond between democracy } \\
\text { and theocracy in Nigeria', HTS } \\
\text { Teologiese Studies/Theological } \\
\text { Studies } 76(1) \text {, a5310. https:// } \\
\text { doi.org/10.4102/hts. } \\
\text { v76i1.5310 }\end{array}$} \\
\hline \multicolumn{2}{|c|}{$\begin{array}{l}\text { Copyright: } \\
\text { (c) 2020. The Authors. } \\
\text { Licensee: AOSIS. This work } \\
\text { is licensed under the } \\
\text { Creative Commons } \\
\text { Attribution License. }\end{array}$} \\
\hline \multicolumn{2}{|l|}{ Read online: } \\
\hline 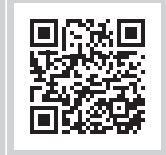 & $\begin{array}{l}\text { Scan this QR } \\
\text { code with your } \\
\text { Smart phone or } \\
\text { mobile device } \\
\text { to read online. }\end{array}$ \\
\hline
\end{tabular}

Democracy as an administrative system is maintained through party representation and election in which everybody is duly represented, and through a constitution which is prepared in the interest of equity, justice and egalitarianism, and through the rule of law which does not permit any form of preferential or partial treatment and judgement. In Nigeria, democracy came into real existence on 29 May 1999. Coincidentally, sharia, which is the theocratic legal system of Islam, was adopted in Zamfara State followed by some other states of the country almost at the same time. This article is aimed at a critical examination of the socio-religious implications of the practice of theocracy in the implementation of the provisions of sharia as state law in the democratic nation, Nigeria. An attempt at interpreting and proffering solutions to the destabilising effects of the adoption of sharia in contradistinction to the legal system provided by the democratic constitution of the country is made. This research adopted a historical approach and was dependent on both primary and secondary sources. The result indicates that the implications of the 'adoption and practice of sharia in some states of Nigeria are manifest in legal duality, religious partiality and social instability.' This article, therefore, recommends for the country a very important aspect of political restructuring, namely, that religion should be separated from politics.

Keywords: Democracy; Theocracy; Doctrine; Church History; Nigeria.

\section{Introduction}

Since the inception of Nigeria as an independent nation in 1960, there has never been an enduring and stable democracy in the country until 1999 when the then military government under General Abudsalam Abubakar handed over the power to a democratically elected government led by Chief Olusegun Obasanjo, a one-time military head of state. Before then, democracy had never survived for up to a decade in Nigeria having been incessantly interrupted by military takeover of power from civilian administrators.

Unfortunately, in the present dispensation when democracy appears to have come to stay in the country, instability has been the order of the day. Although the constitution of the country provides for freedom of religion, the constitution is meant to be the supreme and the only state law in the country. This constitutional provision was made in view of the fact that Nigeria is a secular country. Thus, religious laws are not meant to be adopted by any state, but should only be binding on individual adherents of such religions.

The overall implication of this arrangement is that the Nigerian Muslim as well as the Nigerian Christian and, of course, the entire citizenry are free to manifest and propagate their religious beliefs in worship, teaching, practice and observance, either alone or in a community with others; in public or in private wherever they find themselves within the borders of the country. But no particular religion is meant to interfere or intermingle with the national polity because of the multi-religious nature of the country and her democratic political system.

'Democracy', they say, 'is a politics of freedom', and one of its dividends is national peace and stability as everything is done with mutual agreement in a democratic setting. Theocracy, on the contrary, could be defined as a system of government by religious leaders or a society that is governed by people who are appointed directly or indirectly by God or the gods in which case the people have no input in governance.

Unfortunately in Nigeria, with the adoption and practice of such a theocratic system as sharia in some parts of the country, there is bound to be socio-religious conflicts in such a dimension that peace and stability and security of life and property cannot be guaranteed. 


\section{Democracy in Nigeria}

Democracy is a system of administration where everybody is recognised as everybody participates in governance and the welfare of everybody is the paramount objective of government. This political system is maintained through party representation and election in which everybody is duly represented. A democratic constitution which is prepared in the interest of equity, justice and egalitarianism, and the rule of law which does not permit any form of preferential or partial treatment and judgement are also fundamental features of a democratic system.

By definition, democracy means 'government by persons who are freely chosen by and responsible to the governed' (Mekeen 1951:303). This definition does not run contrary to the most popular definition of democracy given by Abraham Lincoln, one of the celebrated presidents in the history of America, thus: 'Democracy is the government of the people, by the people and for the people'. Commenting on the above definition of democracy, Raphael (1976) submits that the essential idea of democratic government is government by the people. This implies that democracy is essentially 'government by the people', while the other two ideas in the definition that have to do with government as belonging to the people (of the people) and government as being in the interest of the people (for the people) are essentially subsidiary. Contributing further, Raphael (1976) explains, thus:

Strictly speaking, government by all the people should mean unanimous decisions. But this of course is impossible in political matters. Democracy in practice has to mean following the view of the majority. Perhaps, Lincoln's addition of 'for the people', means that the decisive view which for practical purposes must be that of the majority, should seek to serve the interests of all even though it does not have the agreement of all, otherwise there is the danger that the majority rule may become tyranny. (p. 87)

Modern democracy is known for its associative and common interest attributes and characteristics. These attributes and characteristics include the reign of the rule of law, individual rights and freedom, majority rule and minority rights, separation of power, equality of men, the welfare of all, to mention but a few. Ancient democracies, notwithstanding the United States, are today regarded as the oldest world continuous democracy, with a government elected under the constitution since 1787. Since then, the United States has kept on with the duty of seeing to the establishment and support of democracy in various nations of the world, including Nigeria (Arend 1977). In Nigeria, democracy came into real existence on 29 May 1999.

With well over 180 million inhabitants, Nigeria is unarguably the most populous African nation. After independence in 1960, Nigeria was to run a fully democratic government, but military dictatorship, unfortunately, sprang up and took more than 30 years of the country's 58 years of existence as an independent nation. Nevertheless, the country is today considered a democracy, having held general elections -
1999, 2003, 2007, 2011 and 2015 - uninterruptedly. It is on record that from the military handover of power to the civilians in 1999, the People's Democratic Party (PDP) won the presidential, most gubernatorial and most parliamentary elections in the country until 2015 when another party, the All Progressives Congress (APC), for the first time, took the lead in the elections.

Nigeria since its independence has been practising a constitutional democracy. This is a type of democracy where power is shared between the centre (federal government) and the component units (federating units). In a constitutional democracy, there is the presence of rule of law, justice, equity and egalitarianism. Also, the constitution is the supreme guide of the duties, rights and obligations of citizens and the government. According to Nwabueze (2003), constitutional democracy is portrayed as a metaphor of an edifice standing on many pillars: the rule of law, equality and justice, a market-orientated economy, and a democratic ethos. The edifice itself is constituted by a government freely elected by the popular majority, and limited in its powers by a supreme constitution with overriding legal powers. Constitutional democracy refers here to the employment of democracy for debating and validating the constitution - including the constitution of the democratic process itself (Bellamy 2015:1). Unfortunately, the elections have been characterised by undemocratic elements such as massive fraud, electoral abuses, thuggery and rigging, while the resultant governance is often identified with gross looting of national treasury by a few in the corridors of power. What the country witnessed particularly during the sick leave of the late President Umaru Musa Yar' Adua and the whole democratic process from 1999 till date could only be described aptly in the words of J.O. Odey (2002:10) as 'the rape of democracy'. In sum, Nigeria's democracy under the PDP has not measured up any bit to what a democratic system ought to be. This is because a democracy that breeds selfishness, sectionalism, godfatherism, selective electoral process, injustice and political imposition is no democracy at all. Although Goodluck Jonathan-led government appears to have shown some light as to what a true democracy ought to be, yet godfatherism was prominently enthroned in the country during his reign.

Ironically, the 'rape of democracy' using the words of Odey (2002), no doubt, has been most apparent in the present dispensation under Muhammad Buhari as the nation is now being governed without much respect to the rule of law.

One of the dividends of democracy is the enjoyment of social freedom and peace among the citizens. Religion is freely practised by the citizens, but on a personal basis as no religion or religious practice is compulsorily imposed on any citizen or group of the citizenry. But it is observable that this is not the case in Nigeria's democracy as an Islamic religious practice, namely, sharia is gradually being imposed on the entire citizens and inhabitants of the country. The experience 
of the nation in the face of this clash of interests between the democratic ideals of the Nation's constitution on one hand and the theocratic ideals of the Islamic legal code on the other in such states is far from being the dividends of democracy, hence socio-religious freedom and peace can no longer be guaranteed.

\section{Sharia as a theocratic system}

Sharia is a religious legal system, a legal code that was derived from the divine revelations of Allah to Muhammad, the founder of Islam. Gbemi Egunjobi (2000) describes sharia as the divine law of Islam whereby every Muslim lives his life. It embraces every aspect of life, including family relations, inheritance, taxation, purification, prayer and observes no distinction between secular and religious laws. It points out that: 'the best Jihad is that a person speaks the truth he knows'.

Thus, originally, the Jihad was not only a war against unbelievers and non-Muslims. It included conquering one's negative desires, passions, ignorance and diseases. This is an objective lesson for the Islamic fundamentalists and fanatics of today. The Jihad against self should come first.

In its purely religious meaning, sharia can be defined as the canonical law of Islam. It is regarded as 'God given duty, faith and religious obligations which a Muslim must strive for its steadfastness in duty, faith and unity among Muslims' (Egunjobi 2000), so that men may be led to life or a way, to the very source of life.

The word 'sharia' was derived from an Arabic verb 'shari'a' meaning to introduce, prescribe, mould or shape. It also implies to take away, to enact law and to follow a method. The ordinary usage of the word implies the road to a watering place or a path leading to water'. In a nutshell, therefore, sharia ordinarily means 'to follow the path leading to the watering place'. By inference, it could mean the correct path of rectitude laid down by the Supreme Being, Allah, for mankind to follow.

Sharia derived its ethical injunctions from the Quran and the Hadith. It contains a wide range of 'lawful' (halal) and 'forbidden1' (haram) human acts. While the former is that which Allah has made lawful in his Book (Quran), the latter is that which he has forbidden (Quran 6:119, 10:59).

Most non-Muslims tend to regard the sharia as a barbaric penal code. In contrast, the Muslims had argued that:

[S] haria is not a punishment system, but is divided into five main branches, namely; Itigadat (Belief), Ibadah (Ritual), Adab (Morals and Manners); Muamalat (Transactions and Contract); and finally Uqubat (Punishment). (Anas, Dahan \& Yaacob 2016:8)

The overriding aims of the sharia were meant to guide and direct the Muslim to the path of righteousness, to awaken his conscience in his daily actions and to make the 'Ummah'
(Islamic Community) law-abiding and peaceful. When Ahmed Sani Yerima, the former Governor of Zamfara State, was establishing the Sharia in Zamfara in 1999, he was quoted to have argued that his aims were to 'ensure justice, protection of people's lives and property, and sanctity which cannot be guaranteed without making the sharia their guide' (Ezunu 2002).

Sharia dictates the conduct of Muslims and gives the believer the knowledge of what is required by Allah (Al-Wajib), what is disapproved (Al-Makruh), which is forbidden (AlMahzur), what is recommended (Al-Manduh) and what is merely allowed (Al-Mubah). According to Egunjobi (Guardian Newspaper 2000:23), sharia, in essence, is the law that stipulates how a Muslim should live to please Allah. It provides the principles with which an Islamic state should be governed. It also legislates on the treatment of non-Muslims (the unbelievers, 'Kafirun; the Jews, Ahl-Al-Kitab' and the Christians). According to Egunjobi (2000), sharia has been defined as:

An identifiable and generally agreed upon body of general principles of law and ethics accepted by all Muslims as authoritative and binding statements from God. Sharia provides for codes of ethics, social interaction and legal system. It regulates the full range of human activities from religious rituals, social manners and political institutions to, legal rules in civic, commercial, criminal and family. (n.p.)

Sharia is therefore meant to control the whole of a Muslim's life, both private and public. In fact, for the Muslims, sharia is both divine and positive law. As a divine law, it deals with man's relationship with his creator, and as a positive law it concerns humanity and what it takes to live in an Islamic community.

Sharia, therefore, is typically a theocratic legal system being a body of law that derives from divine revelations of Allah and provides the principles with which an Islamic state should be governed. It, thus, runs parallel to a democratic system which is human in origin.

\section{Sharia in Nigeria}

Sharia as the Islamic legal system has been an essential part of the religious and legal life of the Muslims of Northern Nigeria. The system existed in the North for so many years before the coming of the Whiteman. During the colonial era, the penal code of the northern part of the country, no doubt, had Islamic features, but the formulators made sure that any law which had religious connotations was limited in application to the adherents of Islam, and that non-adherents were free from such laws (Ezunu 2002:18). If non-adherents committed any such offence which had religious connotation, the people would face their own religious or customary sanctions. This is no longer the case in Nigeria with the adoption of sharia as a state law as the provisions of sharia have become generally binding on the entire citizenry and inhabitants of some states of the country. 
The adoption of sharia as state law in Nigeria began in Zamfara State on 27 October 1999 at the instance of Governor Ahmad San Yerima (Dambo 2000). Six months after Zamfara State has kicked off the ball, Kano followed suit and later Kaduna joined, and gradually sharia became the official law in all the core northern states of Nigeria (Dabinta 2011). Thus, today, in all such states sharia is for all and not for Muslims only.

The adoption of sharia as state law is not just a religious and moral quest for uprightness in the sight of Allah among Muslims, but it is a significant step towards full Islamisation of a people. In Nigeria, there is, therefore, little or no doubt that sharia has been adopted as state law in some core Muslim-dominated northern states in a bid to gradually Islamise the entire country.

No one questions or denies the freedom constitutionally guaranteed to a Muslim as well as any other Nigerian citizen to manifest and propagate his religion or belief in worship, teaching, practice and observances either alone or in community, in public or in private; hence, in the democratic constitution of Federal Republic of Nigeria, there is provision for freedom of worship (1999 Constitution: Section 38). The major problem with sharia in Nigeria is its imposition on non-Muslims living, especially Christians, in the northern part of Nigeria. Non-Muslims are bound by the Nigerian constitution; hence, any other rules or regulation undermines the national constitution. Also, worthy of mention is the fact that even when the Quran makes it clear that there is no compulsion in religion, directing Muslims to live with their own religion and allowing others to live with theirs (Ezunu 2002:59), politicians and religious extremists and fanatics are wanting to use sharia for achieving their selfish aims, aimed at making Islam look like the dominant religion in Nigeria.

It is on record that in most of the states of the country where sharia is being practised today as a state law, bloody crises were experienced in the process of the adoption, and subsequently, there have been repeated attacks and counterattacks among the citizens in the bid to fully implement the provisions of sharia. Today, the situation is such that most states in the northern part of the country are operating two parallel legal systems as the sharia courts have jurisdiction over several offences beyond personal offences connected with Islamic personal law relating marriage, family inheritance and so on, including theft, unlawful sexual intercourse, robbery, defamation of character and so on, which are supposed to be exclusive reserve of the democratic constitution of the country. Elaigwu and Galadima (2003) reveal that:

Zamfara, Jigawa, Niger, and Sokoto have opted for the fullblown Islamic criminal law for Muslims, with the attendant floggings, decapitations, amputations, and stonings to death, among others, for offenses such as theft, fornication, adultery, and murder. Bauchi, Kano, Katsina, Yobe, Gombe, and Kaduna have opted for a gradual implementation of Sharia in criminal matters. In Kaduna, for instance, amputation of the limbs of thieves, the stoning of adulterers, and hawking by children have been disallowed, while the authorities strictly frown at premarital sex. What has made the practice of Sharia in some northern states especially controversial are sentences of decapitation, amputation, and stoning to death. In addition, there is the selective justice in the implementation of Sharia, and its apparent conflict with certain aspects of the laws of the federation. (p. 140)

The sharia has been seen by some people, especially nonMuslims and moderate Muslim adherents, as subjugating constitutional right to the practice of Islamic religion, and also some punishments prescribed by the new codes, in particular stoning to death and amputation, is inhuman and degrading, and therefore should be regarded as unconstitutional (Weimann 2010:241).The Sharia Legal Code Law (SPCL) violates basic provisions of the constitution of the Federal Republic of Nigeria on human rights and human dignity. In the light of Arend's theory of social plurality (1977:161), Nigeria is nothing other than a plural society, hence the constitution should be the 'ground norm' of her social existence as a country. But it is no longer so. The SPCL raises questions governing personal status law, regulations that pertain to marriage, divorce, inheritance and custody which were $a$ priori interpreted in the constitution (Johnson \& Sergie 2014). Some scholars perceived that the reintroduction of the Sharia penal code was partly because of the perceived noninclusion of the northern elite under Olusegun Obasanjo's presidency because of the assumptions that northern Muslims had lost out in his political reforms, especially as seen in the retirements in the military. Through state Islam, politicians make political capital out of displays of religious allegiance, idioms and patron-client relations; politicians utilise religion to enlarge their political constituency and popular support (Olaniyi 2011:80)

Ironically, sharia as practised in Nigeria is a respecter of persons. So far, the victims of the Sharia Penal Code have been the poor and the powerless people who stole a fowl or a goat or those accused of adultery and so on. The rich and powerful politicians who looted and are still looting the country's treasury go free and are respected. Individuals in this class of people are also involved in such other social offences as adultery, to be particular, but they are always socially immunised, otherwise who has ever heard of any politician in Nigeria being amputated?

\section{Implications of the bond between democracy and sharia}

Since the practice of sharia in some states of Nigeria took the new dimension of marriage between democracy and theocracy, things had never been the same again in the country as many cases of mass killings, maiming, assaults, intimidations, forceful restrictions and deprivations have become the order of the day among the people. The implications of this development on the corporate existence of Nigeria as a multi-religious nation are socio-religious in essence, ranging from legal duality to religious partiality and social instability. 


\section{Legal duality}

The adoption of sharia in some states of Nigeria primarily implies legal dualism - a democratic and theocratic legal systems interfacing in the same country. For a democratic country which is also a multi-religious nation, this is an unhealthy situation. It amounts to a distortion of the nation's legal system and a sectional rebellion to the country's constitution which states that (1999 Constitution):

[T] he whole idea of Nigeria is that it shall be a State based on the principles of democracy and social justice and security, and the welfare of the people shall be the primary purpose of the government. (Section 14)

True democracy cannot thrive in a situation where two legal systems are forced to exist side by side.

A situation where the federal government would be pleading with the judiciary of a particular state in the country on ground of the nation's democratic constitution not to execute someone said to have contravened the sharia law, and the state would insist on executing the person in question amounts to nothing other than a state of legal confusion in the country. The case of Safiya Hussaini clearly represents such a state of legal confusion in Nigeria sequel to the adoption and practice of sharia as state law in some parts of the country. Safiya, a 30-year-old mother of four, was alleged to have been impregnated by a man who was not her husband and based on this an upper sharia court in Gwadabawa, Sokoto State, passed a death sentence on her on 10 October 2001 (Okereocha 2002). Both the then Attorney General and Minister of Justice and the then President Olusegun Obasanjo did not find it easy to rescue the woman from the hands of the sharia protagonists even though the constitution of the federation did not condemn her.

Up till today, Nigerians are still wallowing in that unfortunate state of legal confusion. The citizens are no longer sure whether their country can still be rightly called a democracy given the fact that some states no more hold the constitution as their supreme law. In the same vein, the citizens are no longer sure whether their country is still a secular state because sharia, a religious law, is now the official law of some states of the federation. Worse, still, acts of violent crimes and terrorism by people from a particular part of the country are often subtly swept under the carpet by the government, hence sharia justifies them. The government no longer hides her rape of democracy and denial of the secularity of the nation.

Denying the secularity of the Nigerian state during the official launching of sharia in Zamfara State at the Ali Atiku square on 27 October 1999, Justice Sambo (1999) has this to say:

I like to substantiate my assertion that there was no time, constitutionally, was Nigeria ever a secular State. It is only Nigerians who are misled to regard it so or those who feel they should regard it. So in order to promote their own interest and certainly not the interest of Nigerian Nation. If we examine all the Nigerian Constitutions of the past and present together with the laws, we cannot find any provision, which says Nigeria is a secular State. (p. 40)

According to Sambo and his school of thought, many sections of the constitution contradict secularism: the preamble to the constitution which states that 'the Nation is under God' contradicts secularity; the section on oaths contradicts secularity as oaths are usually taken with religious symbols; the section on education contradicts secularly as the government has to fund education, and education means intellectual and moral training including moral teaching of Muslims and Christians, and moral teaching can only be taught through religion. But as stated in Section 10 of the 1999 Constitution, "The government of the Federation or of any State shall not adopt any religion'. It is this constitutional provision that makes it very plain that Nigeria is a secular state.

Emphasising the above fact, Onaguruwa (2000), a one-time Attorney General and Minister of Justice of the federation, vehemently disagrees with Sambo's assertions with the following remarks:

Section 10 is the provision that makes Nigeria a secular State. By secular, we mean that the State has no particular religion. It does not mean that the nation shall not believe in God or worship him. All it means is that those who hold the sinews of political power must endeavour to separate religion from politics in the result that every individual shall be free to worship God in his own way without State interference. (p. 61)

\section{Religious partiality}

In adopting sharia as state law in some states, Nigerian Muslims fail to take cognisance of the fact that Nigeria is a country with three religions, namely, Christianity, Islam and Traditional Religion. Christians are about 47\%, Muslims about $45 \%$ and traditionalists about $8 \%$. Yet, the Muslims have imposed their own religious legal code on the citizens of many states in the country.

The pains of the religious effect of this development are not on Christians alone. But Christians, of course, bear most of the pains. This is because Christians are in the majority, about $47 \%$ of the population of the country as against other nonMuslims of about $8 \%$.

Samson Bala, the first Anglican Bishop of Gusau Diocese, was said to have revealed that the Radio Station in the state has closed its doors to Christians. Commercials and paid adverts containing Christian literature are not accepted; only Islamic religious programmes are aired. He also stated that there is no Christian Pilgrims' Welfare Board. Other restrictions and deprivations include Churches not being allowed to erect Church buildings on lands, which they legally purchased and Christians being evicted from rented apartments and not getting houses to rent (Dambo 2000:8).

In sharia states, Christian religious knowledge is not tolerated as the sharia places emphasis on Islamic education in all 
facets of life. For instance, in Zamfara State, Christian religious knowledge has been officially banned in all public primary and secondary schools. Also, public funds are being used to fund Islam, the state religion. With this situation, other religions outside Islam do not have any prospects in the sharia states. No evangelisation, no committed discipleship and no freedom of worship, and the fear of losing one's life and property have become a perpetual experience for Christians and other non-Muslims in such states. Yet, they are full citizens of a democratic country that has a constitution which provides for fundamental human rights.

The height of religious partiality was observed when the Christian Association of Nigeria (CAN) in Kaduna State attempted to demonstrate against what the Christians in the state perceived as the wrongful use of the state machinery to impose sharia on the multi-religious, multi-ethnic and cosmopolitan city of Kaduna. Before the demonstration, the leaders of CAN, Kaduna Zone, made concerted efforts to obtain a permit from the same police who granted a permit to the Muslim youths who staged an uninterrupted 5-day rally in support of sharia, but in the case of the Christians, they were not granted permission (Guardian Newspaper, 25 February 2000).

\section{Social instability}

The social bomb planted by the forceful imposition of sharia on the citizens and inhabitants of Zamfara State followed by Kano and Kaduna exploded in many parts of Northern Nigeria shortly after the adoption claiming many lives and subjecting citizens to untold torture, brutal treatments and subjugations. Properties worth billions of naira went down the drain of sharia riots in many parts of the country as a result of demonstrations, counter-demonstrations and retaliations (Guardian Newspaper, 25 February 2000).

It all started on Sunday, 20 February 2000, when the CAN in Kaduna attempted to demonstrate against what the Christians in the state perceived as the wrongful use of the state machinery to impose sharia on the multi-religious, multi-ethnic and cosmopolitan city of Kaduna.

Prior to the demonstration, the leaders of CAN, Kaduna Zone, made concerted efforts to obtain a permit from the same police who granted a permit to the Muslim youths who staged an uninterrupted 5-day rally in support of sharia, but in their case they were not granted. During the peaceful demonstration on Monday, 21 February 2000, an unsuspected but well-armed Muslim Marauders descended on the Christians and the outcome was one of the most violent and bloody religious riots in the country.

Kaduna, Bauchi, Abuja and other parts of Northern Nigeria were again engulfed in sharia riots between 21 and 23 November 2002. Muslim youths protesting alleged blasphemy by This Day Newspaper took to the streets in Kaduna, Bauchi and Abuja, in particular, destroying lives and property.
This was seen as a necessary act of enforcement of sharia provision (Nwosu \& Anyanwu 2002). The Kaduna office of This Day magazine was burnt down during the riot and so were the houses of Stanley Yakubu, Tajudeen Ajibade and many others. It was estimated that about 250 people including a Reverend Father James Odionlyere were killed, while about 16 churches and nine mosques were burnt down. The Nigerian Red Cross said that some 30000 people fled their homes.

The 2010 episodes of violence and war in Jos Plateau State, Kano and other parts of the North in which more than 900 lives were lost (https://ww $\backslash$ v.reii.gious freedom.nigeria) could as well be interpreted as efforts to implement the provisions of sharia, especially that aspect that legislates on Jihad as a religious duty of Muslims. On 19 January 2010, some Muslims were killed in a nearby town of Kuru Karama being the result of a revenge attack on Muslims by Christians against previous attack on them. Thereafter on March 2010 about 200 Christians were massacred in Dogo Nahawa and several nearby villages. Since then there have been incessant reprisal killings in Plateau, Kano, Borno and Bauchi states. According to Kalu (2011), about 8000 lives have been to the crisis and properties worth trillions of naira destroyed.

In recent times, there have also been massive terrorist attacks with heavy loss of lives and property in various parts of the country masterminded by Boko Haram and Fulani Herdsmen terrorists. Boko Haram (which literally means western education is sinful or evil) terrorists had attacked and still attack various parts of the country particularly in the North and killed thousands of Nigerians especially Christians, but including Muslims who they believe are not practising the true tenets of the Islamic faith. They escalated their terrorist activities after the Nigerian Police killed their leader, Muhammed Yusuf, in 2009 (Ukoha 2018). Since then, they have unleashed terror to the citizenry wantonly destroying lives and property and forcefully driving citizens from their homes to internally displaced persons' (IDP) camps.

Also, the Fulani Herdsmen (ironically, herdsmen fully armed with AK 47 and other dangerous weapons) are making serious incursions into the Middle Belt, especially Benue State and some states in the South. Their attacks appear more sporadic and widespread. They attack communities in the night when the inhabitants would be sleeping, killing hundreds of people in each case and destroying churches and homes. Some of the states that have been so far affected are Benue, Taraba, Enugu, Gombe, Adamawa and Kaduna states (Ukoha 2018).

These two movements - Boko Haram and Fulani Herdsmen and their secret religious sponsors are committed to full implementation of sharia in Nigeria through total Islamisation of the country. Through their activities of forceful displacement and occupation, Islam has taken over the far North and is making serious inroad into the Middle Belt and the Southern part of the country (Achunike \& Kitause 2016). In many occasions, they boldly own up such 
terrorist attacks claiming that Nigeria is the inheritance given to them by Allah and threatening to continue to further their activities until they take over the entire country.

\section{Recommendations}

Many Nigerians do not know that the current terrorist attacks going on in various parts of the country are practical cases of implementation of sharia embedded in a long-term Jihadist programme of establishing an Islamic state of Nigeria. The masterminds have resolved that it is either the non-Muslims in the country submit to the rule of Allah or the country shall remain in a perpetual instability and insecurity.

By way of attempting solutions to the endemic social and religious problems associated with the practice of sharia as a state law in Nigeria, the following recommendations are hereby put forward:

1. Firstly, to avoid religious partiality in Nigeria, the government should separate religion from politics because since the country is a multi-religious nation through ensuring that in any interpretation that involves the rights of the citizens, the constitution should be consulted rather than any religious ethos or dogma.

2. Secondly, any person that does not believe in the supremacy of the nation's democratic constitution should not be elected into any position of political authority in the country.

3. Thirdly, any state or group that flouts the authority of the federal government or violates any of the provisions of the constitution of the federation should be seriously cautioned, then sanctioned if there is persistence.

4. Fourthly, in those states that have adopted sharia and those that may wish to do so in future, sharia should be given the same place that the customary law occupies in the Nigeria. This is because other states in Nigeria have their own customary laws.

5. Fifthly, looking at sharia legal code, it was advance to the detriment and punishment of the poor, while the rich offenders go unpunished. Sharia did not mention what should be done to a politician who was caught stealing millions of naira or diverted thousands of public fund. In other words, sharia should not be a respecter of persons or class.

\section{Conclusion}

Naturally, in any part of the human society, marriage between democracy and theocracy cannot be compatible. In the Nigerian situation, the most perturbing of the implications of the situation is manifest in social instability. This phenomenon is clearly seen today in the country in the incessant acts of violence and terrorism that are being unleashed on innocent citizens of the country without serious investigations and prosecutions of the culprits by the government. The bottom line of the matter is that the Nigerian Muslims in the bid to widen the geographical jurisdiction of sharia have developed a kind of aggressive and militant attitude towards
non-Muslims, especially in those areas where Christians are dominating. This, advertently or inadvertently, is aimed at forcefully bringing the entire country into an Islamic state that will be ruled under the full tenets of the sharia. And unfortunately, the government is doing nothing about it. There is nothing wrong in a sincere desire by Muslims to live under the provision of sharia. Islamic religion is their choice and so they are free to live under its legal system. The essence of sharia is for the Muslims to live in accordance with the stipulations and dictates of their faith, hence sharia should be applied to Muslims only.

Anything outside this poses a destabilising problem to Nigeria as a democratic and multi-religious nation.

\section{Acknowledgements}

The authors thank Prof. E. van Eck, Prof. Andries van Aarde and the entire team of HTS for their efforts in getting this work published.

\section{Competing interests}

The authors have declared that no competing interest exists.

\section{Authors' contributions}

All authors contributed equally to this work.

\section{Funding information}

This research received no specific grant from any funding agency in the public, commercial or not-for-profit sectors.

\section{Data availability statement}

Data sharing is not applicable to this article as no new data were created or analysed in this study.

\section{Disclaimer}

The views and opinions expressed in this article are those of the authors and do not necessarily reflect the official policy or position of any affiliated agency of the authors.

\section{References}

Achunike, H.C. \& Kitause, R.H., 2016, 'Christianity, mission and education in Nigeria', International Journal of Christian Theological Research 5(1), 12-17.

Anas, N., Dahan, A.F.M. \& Yaacob, Z., 2016, 'Basic principles of Shariah: UiTM Law Foundation student's attitude \& perceptions', Jurnal Intelek 10(2), 7-1.

Arend, L., 1977, Democracy in plural societies: A comparative exploration, University of Ibadan Press, Ibadan.

Bellamy, R., 2015, 'Constitutional democracy', in M.T. Gibbons (ed.), The encyclopedia of political thought, pp. 97-100, John Wiley \& Sons, Ltd, East Orange, NJ.

Constitution of the Federal Republic of Nigeria [Nigeria], 1999, viewed 24 November 2019, from http://www.nigeria-law.org/ConstitutionOfThe FederalRepublicOfNigeria.htm.

Dambo, P., 2000, 'Adoption of Sharia in Zamfara state', The Guardian Newspaper, 02 March, p. 1.

Egunjobi, G., 2000, 'Sharia and the women', The Guardian Newspaper, 25 March, p. 1. 
Elaigwu, J.I. \& Galadima, H., 2003, 'The shadow of sharia over Nigerian Federalism' Publius: The Journal of Federalism 33(3), 123-144. https://doi.org/10.1093/ oxfordjournals.pubjof.a004995

Ezunu, S.C., 2002, The socio-political and religious effect of the sharia in Nigeria society, B.A. Project, Trinity College, Umuahia.

Johnson, T. \& Sergie, M.A., 2014, Islam: Governing under sharia (aka shariah, sharia) viewed 25 July 2014, from https://www.netadvisor.org/wp-content/uploads/ 2014/09/2014-00-00-Islam -Governing-Under-Sharia-Council-on-ForeignRelations.pdf.

Kalu, U., 2011, A cycle of reprisals turns Jos into killing field, viewed 24 November 2019, from https://www.vanguardngr.com/2011/12/a-cycle-of-reprisals-turnsjos-into-killing-field/.

Mekeen, R. (ed.), 1951, Democracy in a world of tension, University of Chicago Press, Chicago, IL.

Nwabueze, B. (ed.), 2003, 'The return of Africa to constitutional democracy', in Constitutional democracy in Africa, vol. 5, pp. 1-12, Spectrum Books, Nigeria.

Nwosu, I. \& Anyanwu, G., 2002, 'Miss World pageant canceald', The Sunday Champion, 24 November, p. 1
Odey, J.O., 2002, Democracy: Our lofty dreams and crazy ambitions, Snaap Press Ltd, Enugu.

Okereocha, C., 2002, 'Should Safiya die?', Newswatch Magazine, 03 December, vol. 34, p. 22.

Olaniyi, R.O., 2011, 'Hisbah and sharia law enforcement in Metropolitan Kano', Africa Today 57(4), 71-96. https://doi.org/10.2979/africatoday.57.4.71

Onaguruwa, O., 2000, 'The furore about sharia', The Guardian Newspaper, 20 March, p. 1.

Raphael, D.D., 1976, Problems of political philosophy, 2nd rev. edn., Macmillan Press Ltd, London.

Sambo, M.B., 1999, 'Adoption of sharia in Zamfara state', The Guardian Newspaper, 02 March, p. 1.

Ukoha, E.I., 2018, 'The church in Nigeria and internal security management, 2009-2017', A seminar paper presented to the department of religion and cultural studies, University of Nigeria, Nsukka, 22 March 2018.

Weimann, G.J., 2010, Islamic criminal law in northern Nigeria: Politics, religion, judicial practice, Amsterdam University Press, Amsterdam. 